$11-1-2017$

\title{
The Uncompensated Takings of Nuisance Law
}

Jill M. Fraley

Follow this and additional works at: https://digitalcommons.law.villanova.edu/vlr

Part of the Property Law and Real Estate Commons

\section{Recommended Citation}

Jill M. Fraley, The Uncompensated Takings of Nuisance Law, 62 Vill. L. Rev. 651 (2017).

Available at: https://digitalcommons.law.villanova.edu/vlr/vol62/iss4/2

This Article is brought to you for free and open access by Villanova University Charles Widger School of Law Digital Repository. It has been accepted for inclusion in Villanova Law Review by an authorized editor of Villanova University Charles Widger School of Law Digital Repository. 
Fraley: The Uncompensated Takings of Nuisance Law

2017]

THE UNCOMPENSATED TAKINGS OF NUISANCE LAW

\author{
JiLl M. FraleY*
}

\title{
I. INTRODUCTION
}

$\mathrm{N}$

UISANCE law has long since graduated from the boundaries of property and tort to influence a variety of fields from environmental law ${ }^{1}$ to patents, ${ }^{2}$ domestic violence prevention ${ }^{3}$ to drug con-

* Associate Professor of Law, Director, Center for Law and History, Washington and Lee University School of Law. Thanks to Bob Bone, Molly Brady, Al Brophy, Ben Edwards, Donald Kochan, Brian Murchison, Caroline Osborne, and Lisa Pruitt. I appreciate the research assistance of Alix Sirota, Matthew Donahue, and Meredith Toole.

1. Nuisance has become a key part of environmental law across a variety of different sub-fields and issues. See, e.g., Stephen Harland Butler, Headwinds to a Clean Energy Future: Nuisance Suits Against Wind Energy Projects in the United States, 97 Calif. L. Rev. 1337, 1337 (2009) (renewable energy); David A. Dana, The Mismatch Between Public Nuisance Law and Global Warming, 18 S. Ст. Econ. Rev. 9, 9-10 (2010) (global warming); Andrew Jackson Heimert, Keeping Pigs out of Parlors: Using Nuisance Law to Affect the Location of Pollution, 27 ENVTL. L. 403, 403 (1997) (citing of polluters); Tracy D. Hester, A New Front Blowing In: State Law and the Future of Climate Change Public Nuisance Litigation, 31 Stan. EnvTL. L.J. 49, 50 (2012) (climate change); Albert C. Lin, Deciphering the Chemical Soup: Using Public Nuisance to Compel Chemical Testing, 85 Notre Dame L. Rev. 955, 958 (2010) (toxins regulation); Matthew Edwin Miller, The Right Issue, the Wrong Branch: Arguments Against Adjudicating Climate Change Nuisance Claims, 109 MicH. L. Rev. 257, 259 (2010) (climate change litigation); Endre Szalay, Breathing Life into the Dead Zone: Can the Federal Common Law of Nuisance Be Used to Control Nonpoint Source Water Pollution?, 85 Tul. L. Rev. 215, 215 (2010) (water pollution); see also Joseph F. Falcone III \& Daniel Utain, You Can Teach an Old Dog New Tricks: The Application of Common Law in Present-Day Environmental Disputes, 11 Vill. ENVTL. L.J. 59, 65 (2000) (discussing general applicability of common law nuisance claims to modern environmental issues).

2. See Richard A. Crudo, A Patently Public Concern: Using Public Nuisance Law to Fix the False Patent Marking Statute After the Leahy-Smith America Invents Act, 80 GEO. WAsh. L. Rev. 568, 573 (2012) (discussing relevance of nuisance doctrine for patent litigation); Janet Freilich, A Nuisance Model for Patent Law, 2011 U. ILL. J.L. TECH. \& POL'y 329, 330 (2011) (proposing using nuisance framework to determine remedies in patent litigation); Christopher M. Newman, Patent Infringement as Nuisance, 59 CATH. U. L. Rev. 61, 67-68 (2009) (discussing applying nuisance law to patent infringement cases).

3. See Gretchen Arnold \& Megan Slusser, Silencing Women's Voices: Nuisance Property Laws and Battered Women, 40 LAw \& Soc. InQuiry 908, 908-09 (2015) (discussing how property laws discourage domestic violence victims from seeking assistance); Sarah Swan, Home Rules, 64 Duke L.J. 823, 825 (2015) (discussing nuisance ordinances in context of domestic violence and eviction); Amanda K. Gavin, Comment, Chronic Nuisance Ordinances: Turning Victims of Domestic Violence into "Nuisances" in the Eyes of Municipalities, 119 PENN. ST. L. Rev. 257, 261-62 (2014) (discussing municipal ordinances that target chronic nuisances, including domestic violence); Filomena Gehart, Note \& Comment, Domestic Violence Victims a Nuisance to Cities, 43 Pepp. L. Rev. 1101, 1102 (2016) (discussing eviction of domestic violence victims due to city nuisance ordinances); Anna Kastner, Comment, The 
Villanova Law Review, Vol. 62, Iss. 4 [2017], Art. 2

trol, ${ }^{4}$ products liability ${ }^{5}$ to the recent mortgage and financial crisis. ${ }^{6}$ As this progression demonstrates, nuisance law deeply influences an astonishing number of legal fields and issues. ${ }^{7}$

In addition to the direct impacts of nuisance law on other fields, nuisance doctrines have become a significant part of the more theoretical literature, particularly within the law and economics movement. Nuisance was a key part of Guido Calabresi and A. Douglas Melamed's famous article on the economics of tolerating pollution. ${ }^{8}$ Other scholars have followed their lead and used nuisance as a point of entry for analyzing property and tort from a law and economics perspective. ${ }^{9}$

Other War at Home: Chronic Nuisance Laws and the Revictimization of Survivors of Domestic Violence, 103 CaLIF. L. REv. 1047, 1048-50 (2015) (describing chronic nuisance laws as targeting victims of domestic violence).

4. See Chad DeVeaux \& Anne Mostad-Jensen, Fear and Loathing in Colorado: Invoking the Supreme Court's State-Controversy Jurisdiction to Challenge the MarijuanaLegalization Experiment, 56 B.C. L. Rev. 1829, 1833 (2015) (discussing constitutional law issues associated with interstate nuisance disputes involving legalized marijuana). Notably, nuisance has long been used as a method of addressing morally censured activities such as gambling and prostitution. See generally John Copeland Nagle, Moral Nuisances, 50 Emory L.J. 265 (2001), for a discussion on the relationship between nuisance and morality.

5. See Victor E. Schwartz, Phil Goldberg \& Corey Schaecher, Game over? Why Recent State Supreme Court Decisions Should End the Attempted Expansion of Public Nuisance Law, 62 OKLA. L. Rev. 629, 630-31 (2010) (describing efforts to avoid traditional defenses in products liability cases by using nuisance as cause of action); Eric L. Kintner, Note, Bad Apples and Smoking Barrels: Private Actions for Public Nuisance Against the Gun Industry, 90 IowA L. Rev. 1163, 1168 (2005) (discussing liability of gun industry for firearms related deaths).

6. See Melissa C. King, Recouping Costs for Repairing "Broken Windows": The Use of Public Nuisance by Cities to Hold Banks Liable for the Costs of Mass Foreclosures, 45 TORT Trial \& Ins. Prac. L.J. 97, 99-100 (2009) (discussing attempts by cities to hold lenders liable for the local costs of mass foreclosures); Matthew Saunig, Note, Rebranding Public Nuisance: City of Cleveland v. Ameriquest Mortgage Securities, Inc. As a Failed Response to Economic Crisis, 59 Cath. U. L. Rev. 911, 912-13 (2010) (describing case in which City of Cleveland pursued twenty-one lenders as public nuisance related to subprime mortgage crisis).

7. For better or worse. As William L. Prosser once observed, "There is perhaps no more impenetrable jungle in the entire law than that which surrounds the word "nuisance." William L. Prosser, Handbook of the Law of Torts, § 86, at 571 (4th ed. 1971). For this reason, it is fair to question the sanity of anyone who undertakes to write an article about the evolution of the doctrine of nuisance. Guilty. In my defense, only two statements can really be made. First, this Article focuses specifically on the idea of balancing and nuisance. That does something to bring the project within the realm of manageability. Second, while this Article does attempt (perhaps somewhat unreasonably) to roughly track the many states as a whole, it does not attempt to lay out the doctrine in full in any jurisdiction. Rather the Article focuses on trends that are apparent across some to many jurisdictions at key points in time. The overall argument focuses on what can be noticed from these trends, without needing to argue that the trends are simultaneous or that the doctrines exactly align across jurisdictions.

8. See generally Guido Calabresi \& A. Douglas Melamed, Property Rules, Liability Rules, and Inalienability: One View of the Cathedral, 85 Harv. L. Rev. 1089 (1972).

9. See, e.g., Lucian Arye Bebchuk, Property Rights and Liability Rules: The Ex Ante View of the Cathedral, 100 Mich. L. Rev. 601, 603-04 (2001) (using pollution as 
One might expect, given the importance of nuisance law in terms of its both theoretical and practical impacts, that a great deal of effort would be invested in the process of understanding the doctrine's intricacies, history, and evolution. Yet few scholars have examined the evolution of nuisance law. In 1976, Paul Kurtz published an article on the history of injunctive remedies for nuisance during the industrial rise of the nineteenth century. ${ }^{10}$ Kurtz focused on the ability of defendants to avoid injunctions through largely procedural devices that limited or stalled injunctions and left plaintiffs to seek damages remedies instead. ${ }^{11}$

Little has been written about the transformation that took place in the twentieth century. In an article about compensated injunctions and nuisance law, Jeff Lewin briefly addressed the history of nuisance law. ${ }^{12}$ As Lewin's central point lay elsewhere, his discussion was limited. But we can point to a few key claims that Lewin made. Lewin believed that a significant change had happened within nuisance law, finding that "[i]n the nineteenth century America witnessed a profound evolution of nuisance doctrine from its roots in property law into a doctrine of tort law." 13 Overall, Lewin glimpsed a trajectory of decreasing liability until environmental concerns of the 1960s and 1970s pushed back against the idea of allowing social utility to entirely outweigh a plaintiff's concerns. ${ }^{14}$ Both Kurtz and Lewin place the moment of significant change in the nineteenth century, when courts moved nuisance law from a strict liability formulation to ideas of mitigating factors. ${ }^{15}$ This change indeed occurred, but it is not the only moment of transformation of nuisance law, nor, indeed, the most important one.

This Article argues that a significant transformation of nuisance law took place in the mid-to-late twentieth century. Prior to that time, through two mechanisms-the reasonableness test and injunction re-

primary example of harm to neighboring property); Eric R. Claeys, Jefferson Meets Coase: Land-Use Torts, Law and Economics, and Natural Property Rights, 85 Notre Dame L. Rev. 1379, 1398-99 (2010) (focusing on land-use torts, of which nuisance cases form substantial part); Louis Kaplow \& Steven Shavell, Property Rules Versus Liability Rules: An Economic Analysis, 109 Harv. L. Rev. 713, 748-56 (1996) (using industrial pollution and nuisance cases as examples).

10. See generally Paul M. Kurtz, Nineteenth Century Anti-Entrepreneurial Nuisance Injunctions-Avoiding the Chancellor, 17 WM. \& MARY L. Rev. 621 (1976). Kurtz discussed the Industrial Revolution and concluded that applying the traditional and strict approach to nuisance in a developing economy would have "burdened the entrepreneur with a heavy potential liability." See id. at 623. Indeed, injunctive liability in specific, he says, "would have effectively stopped all entrepreneurial activity." See id. As a result, industrialization would have faced "a serious, if not insurmountable, obstacle." See id.

11. See id. at 630 .

12. See Jeff L. Lewin, Compensated Injunctions and the Evolution of Nuisance Law, 71 Iowa L. Rev. 775, 779-85 (1986).

13. See id. at 779 (alteration in original).

14. See id. at 783 .

15. See Kurtz, supra note 10, at 622-23; Lewin, supra note 12, at 779. 
Villanova Law Review, Vol. 62, Iss. 4 [2017], Art. 2

quests-courts had begun to balance social utility as a part of a nuisance case. ${ }^{16}$ This change was not at all an open door to reducing nuisance claims. Instead, courts sharply limited balancing, usually to injunction decisions, so as to protect property rights. ${ }^{17}$ This continued through the first half of the twentieth century with early courts accepting balancing but also limiting it sharply. ${ }^{18}$

Tracing these limitations forward into the twentieth century, I demonstrate that within the mid-to-late twentieth century, a revisionist trend emerged. Nuisance law transformed as courts dropped longstanding limits on balancing and fully embraced weighing the harms to the defendant as well as the public. ${ }^{19}$ In this same era, courts revised the concept of reasonableness, moving it from an analysis of property contexts to a balancing inquiry that included both social utility and potential harms to the defendant. ${ }^{20}$ This change significantly altered property rights because when courts incorporated balancing into the prima facie case for nuisance (as opposed to only allowing balancing within the equitable remedies analysis), courts made it much more difficult for plaintiffs to succeed. Contrary to Lewin's more optimistic view of modern nuisance law, I argue that modern nuisance law is characterized by a lack of limits on balancing and a trajectory of making even damages awards less available.

This transformation of nuisance law-the removal of limits on balancing and the full embrace of the reasonableness test in the prima facie case-makes nuisance actions more difficult to win. As a result, modern courts protect property less-a lot less-than fifty years or so ago. Mostly notably, this evolution of the key elements of nuisance has happened in a rather slow, gradual, and sneaky fashion. It has been largely under the radar. So courts have, effectively, reduced property rights without much fanfare and without an opportunity for the public to consider this transformation of property law.

Most importantly, courts have made the same changes to nuisance law that they previously described as creating regulatory takings claims. Yet, as I will explain, courts adopted those changes with little explanation and no rebuttal to their prior concerns about regulatory takings.

In light of the danger of takings and the reduction of property rights associated with curtailing the scope of nuisance claims, I argue that courts today need to reconsider nuisance law and return to limiting all balancing inquiries to injunction decisions. Courts again reject balancing within the prima facie case. Such a revision would allow balancing to limit injunctive remedies and thereby take into account the public interest as necessary,

16. See infra notes $27-58$ and accompanying text.

17. See infra notes 59-68 and accompanying text.

18. See infra notes 86-92 and accompanying text.

19. See infra notes $93-113$ and accompanying text.

20. See id. 
but it also would allow plaintiffs to recover money damages if a nuisance is otherwise provable.

This Article begins in Part II by focusing on early nuisance doctrines so as to set up the contrast of the original strict liability formulations of nuisance law with modern developments. ${ }^{21}$ I also pause here to clarify the original meaning of reasonableness as a part of the nuisance test. This is important because it was through the element of reasonableness that courts were later able to introduce balancing into the prima facie case-as opposed to reserving balancing for solely the question of injunctive remedies. In Part III, I discuss the early life of balancing in the first half of the twentieth century, explaining the many limitations that courts placed upon the doctrine. ${ }^{22}$ After examining the most powerful limitations individually, I conclude this Part by describing how many courts and commentators combined these limitations to even further restrict balancing. Part IV details how revisionist courts from the mid-to-late twentieth century (1) dispensed with the many limits on the balancing doctrine, (2) embraced a more general idea of balancing, and (3) more clearly seated balancing within the prima facie case, incorporating a balancing analysis in cases seeking only damages as a remedy ${ }^{23}$ Part V focuses on the implications of this transformation of nuisance law for property. ${ }^{24}$ I examine the degree to which changes in nuisance doctrine make the courts more and more likely to engage in regulatory takings. Additionally, I consider theoretically what the transformation of nuisance means in terms of the right of undisturbed possession. Finally, I argue that modern courts should, in light of the dangers of takings, consider returning to the practice of early courts of limiting balancing to the consideration of equitable remedies. Courts should reconstruct the older strain of thinking on nuisance law, removing balancing from the prima facie case, so that plaintiffs are at least protected in their right to damages, even if injunctive remedies are limited by balancing social utilities and the harms to the defendant.

\section{Early Nuisance Doctrines}

Traditionally, the nuisance action protected property quite strictly. Indeed, that protection has often been described as absolute or complete. ${ }^{25}$ Two things ensured this level of protection. First, courts applied the doctrine as a strict liability style enterprise, imposing "absolute liability for interference with the enjoyment of property." ${ }^{26}$ Section A describes how this approach allowed for no balancing of the harms to the defendant or the local community when a court considered whether to issue an in-

21. See infra notes $25-58$ and accompanying text.

22. See infra notes 59-142 and accompanying text.

23. See infra notes 143-79 and accompanying text.

24. See infra notes 180-210 and accompanying text.

25. See id. at 779 .

26. See Kurtz, supra note 10, at 622. 
Villanova Law Review, Vol. 62, Iss. 4 [2017], Art. 2

junction. Second, while courts did consider reasonableness as a part of the test for nuisance, this did not involve a balancing of harms or a social utility style analysis. Section B focuses on the original definitions of reasonableness, which did not include balancing harms or social utility but instead focused on the physical context of the land use.

\section{A. Strict Liability on a Finding of Nuisance}

The traditional nuisance doctrine strictly protected property. Thus, "[a] judgment for damages in this class of cases is a matter of absolute right, where injury is shown." 27 The traditional rule refused balancing because it was not a just principle that "a nuisance in one place may be compensated by any degree of benefit conferred in another." 28 The central problem with balancing, the New Hampshire Supreme Court recognized, was that " $[\mathrm{n}]$ o comparison can be instituted between accommodation to one set of persons and loss of rights to another." 29

In the most traditional formulation of the rule, even public necessity was not enough to limit this strict formulation of nuisance law. The 1942 American Jurisprudence statement on nuisance noted that " $[i] \mathrm{t}$ has been said that in determining whether a business is a nuisance, it is of no consequence that the business is a useful or necessary one, or that it contributes to the wealth and prosperity of the community." ${ }^{0}$ Following this approach, the New Hampshire Supreme Court, for example, found that while slaughterhouses were necessary, that necessity did not legalize the intrusions such businesses could make onto the property of other landowners. ${ }^{31}$ It was of no matter that the business creating the nuisance was "a great and essential accommodation to the public." ${ }^{32}$ The traditional rule was that "the court would not balance conveniences, but, when the violation of the public or private right was clear, there could be no excuse heard of public convenience that would protect the person or corporation committing the nuisance." ${ }_{33}$ The defendant simply would "not be permitted to show that the public benefit resulting from the alleged nuisance was

27. Louisville \& N. Terminal Co. v. Lellyett, 85 S.W. 881, 888 (Tenn. 1904) (alteration in original) (quoting Madison v. Ducktown Sulphur, Copper \& Iron Co., 83 S.W. 658, 664 (Tenn. Ct. App. 1904)).

28. See Conn. River Lumber Co. v. Olcott Falls Co., 21 A. 1090, 1094 (N.H. 1889) (quoting R. v. Ward [1836] 111 Eng. Rep. 832, 834; 4 Adol. \& E. 384, 393-94).

29. See id. (alteration in original).

30. See 39 Am. Jur. Nuisances $§ 45$, at 327 (1942). The treatise goes on to note that there are only two exceptions to this rule. See id. The first is for criminal prosecutions for nuisance. See id. The second suggests that some courts will consider social utility in granting an injunction, but not in the context of a damages decision. See id.

31. See Conn. River Lumber, 21 A. at 1094.

32. See Seacord v. Illinois, 13 N.E. 194, 200-01 (Ill. 1887).

33. See id. at 200. 
equal to the public inconvenience occasioned thereby." 34 Nor was the court interested in hearing evidence that this particular defendant was "less offensive than any other answering the same public demand." 35

Courts following the traditional rule refused to consider balancing even where the damage to the defendant resulting from issuing an injunction was quite substantial. Consider, for example, the Court of Appeals of Maryland case Susquehanna Fertilizer Co. v. Malone. ${ }^{36}$ The court concluded that it would not "undertake to balance the conveniences, or estimate the difference between the injury sustained by the plaintiff and the loss that may result to the defendant from having its trade and business, as now carried on, found to be a nuisance." 37 The court's reasoning was a simple affirmation of the strength of property rights: "No one has a right to erect works which are a nuisance to a neighboring owner, and then say she has expended large sums of money in the erection of his works, while the neighboring property is comparatively of little value." 38 The court pulled no punches in its final conclusion: "The neighboring owner is entitled to the reasonable and comfortable enjoyment of his property, and, if his rights in this respect are invaded, he is entitled to the protection of the law, let the consequences be what they may." 39 The simple rule was that "courts of equity will not balance the inconvenience of a tortious wrongdoer against one whose rights have clearly been infringed upon." 40

This strict rule was necessary, courts reasoned, because "[t]o hold otherwise would be to compel the citizen to abandon his property at the demand of the public convenience." ${ }^{41}$ Balancing was, for these courts, simply an "irrelevant question." ${ }^{2}$ The strict rule protecting property existed because the courts reasoned that it was protecting already established property rights, specifically the "rights of habitation" of the neighboring landowners. ${ }^{43}$

Early twentieth century courts regularly not only rejected balancing, but also suggested that the injunctive remedy was a matter of right when such property rights had been invaded. ${ }^{44}$ Such courts reasoned that refus-

34. See id. (citing R. v. Ward [1836] 111 Eng. Rep. 832; 4 Adol. \& E. 384).

35. See id. at 200-01.

36. See Susquehanna Fertilizer Co. v. Malone, 20 A. 900, 902 (Md. 1890).

37. See id.

38. See id.

39. See id. 1933).

40. See Baldocchi v. Four Fifty Sutter Corp., 18 P.2d 682, 687 (Cal. Dist. App.

41. See Seacord v. Illinois, 13 N.E. 194, 201 (Ill. 1887).

42. See Davis v. Palmetto Quarries Co., 48 S.E.2d 329, 331 (S.C. 1948).

43. See Ritz v. Woman's Club of Charleston, 173 S.E. 564, 565 (W. Va. 1934).

44. See Deterding v. Cent. Ill. Pub. Serv. Co., 231 Ill. App. 542, 559 (1923) (stating that where nuisance exists and "the damages are of a nature which cannot be adequately compensated for in an action at law, a court of equity will grant an injunction. In such a case the court will not balance public benefits or public inconvenience against the individual right." (quoting Wente v. Commonwealth 
Villanova Law Review, Vol. 62, Iss. 4 [2017], Art. 2

ing to grant an injunction "upon the ground that plaintiff cannot suffer as great a loss from the continuance of the nuisance as defendant would from its interdiction, would be as far removed from equity as can be." ${ }^{45}$ The Illinois Appellate Court applied this reasoning, finding that there was a right to injunctive remedies. ${ }^{46}$ The court found that:

[I]f a business is offensive to such a degree as to materially interfere with ordinary physical comfort, measured, not by the standard of persons of delicate sensibilities and fastidious habits, but by the habits and feelings of ordinary people, and the damages are of a nature which cannot be adequately compensated for in an action at all, a court of equity will grant an injunction." 47

Other courts responded similarly: "The use of property that produces a nuisance may be very convenient to the owner, and even convenient and useful to the public, but if the effects are such as to bring it within the legal idea of a nuisance, this furnishes no defense whatever." 48

Notably, some courts went so far as to fully reject balancing even in the context of a temporary or preliminary injunction. In these circumstances, the Supreme Court of Alabama, for example, backed away from "conditioning or qualifying the absolute right to injunctive process." 49 Instead the court found that "even on hearing for the temporary writ, that the relative prejudice between the parties resulting from the granting or the refusal to grant the writ was "wholly immaterial." "50

\section{B. Reasonableness Without Balancing}

In early cases, reasonableness did not involve balancing-at least not balancing in terms of the hardship resulting from an injunction and the advantage to the other party of granting the injunction. Instead, in early cases reasonableness was more a question of what rights a party had to use her own property before she impinged on the property of her neighbor. Courts have observed that reasonableness was a general limit on the ability

Fuel Co., 83 N.E. 1049, 1052 (Ill. 1908))); Riter v. Keokuk Electro-Metals Co., 82 N.W.2d 151, 160-61 (Iowa 1957); Storey v. Cent. Hide \& Rendering Co., 226 S.W.2d 615, 619 (Tex. 1950) (noting that number of decisions "ignore the balance of injury doctrine" and "seemingly authorize the grant of an injunction as a matter of right where the facts present a clear case of nuisance" (citation omitted)).

45. Crew v. Gallagher, 58 Pa. D. \& C. 226, 243-44 (Chester Cty. Ct. Com. Pl. 1946), reversed, 58 A.2d 179 (Pa. 1984) (quoting Evans v. Reading Chem. \& Fertilizing Co., 28 A. 702, 709 (Pa. 1894)).

46. See Deterding, 233 Ill. App. at 544.

47. Id. at 559-60.

48. Brown v. Village of St. Bernard, 20 Ohio Dec. 422, 426 (C.P. 1910) (quoting H.G. Wood, The Law of Nuisances, \$ 75, at 104 (3d ed. 1893)). 1919).

49. See Folamr Mercantile Co. v. Town of Luverne, 83 So. 107, 108 (Ala.

50. See id. at 108 (citing Bank v. Tyson, 32 So. 144, 149 (Ala. 1902)). 
of the government to declare things to be nuisances. ${ }^{51}$ Whether or not something was unreasonable, then, was a conclusion of law. ${ }^{52}$

Reasonableness was about understanding the conflicting rights of neighbors: "Ordinarily one has a right to use his property as she sees fit, but a man's dominion over his own premises is qualified to the extent that his use of them must be reasonable and such as not to create a nuisance." 53 The flip side of nuisance has always been that parties have a right "to use their own property in every reasonable way." 54 To determine whether or not there is a nuisance, the court would "say whether or not the use of the property in the manner complained of is reasonable, and in accordance with the relative rights of the parties." 55

The reasonable use of property, then, was not about balancing rights but about examining the particular circumstances presented by a given case. As a New York case explained, "As to what is reasonable use of one's own property cannot be defined by any certain general rules, but must depend upon the circumstances of each case." ${ }^{56}$ General rules did not help because "[a] use of property in one locality and under some circumstances may be lawful and reasonable, which, under other circumstances, would be unlawful, unreasonable and a nuisance." ${ }^{57}$ The purpose of looking to circumstances was to determine the degree of the invasion of rights: "There can be no fixed standard as to what noise constitutes a nuisance, and the circumstances of the case must necessarily influence the decision ... [t] he location and surroundings must be considered." 58 Traditionally, then, reasonableness was not about balancing but rather about the context of the land use.

\section{The Nuisance Balancing in the Early Twentieth Century:}

\section{SHARP LIMITS}

At the outset, it is important to clarify an issue of terminology. When courts began to integrate balancing into nuisance doctrine in the late nineteenth century, they used a variety of phrases used to describe the court's task. Some courts spoke of "balancing the equities," "balancing the conveniences," "balancing the hardships," and others spoke of the "doc-

51. See Glucose Ref. Co. v. City of Chicago, 138 F. 209, 213 (N.D. Ill. 1905).

52. See Exley v. S. Cotton Oil Co., 151 F. 101, 104 (S.D. Ga. 1907).

53. See Sam Warren \& Son Stone Co. v. Gruesser, 209 S.W.2d 817, 819 (Ky. Ct. App. 1948).

54. See Lamb v. Reclamation Dist. No. 108, 14 P. 625, 627 (Cal. 1887) (quoting H.G. Wood, The Law of Nuisances $§ 1$, at 21 (3d ed. 1893)).

55. See id. $1905)$.

56. See Bentley v. Empire Portland Cement Co., 96 N.Y.S. 831, 833 (S. Ct.

57. See Campbell v. Seaman, 63 N.Y. 568, 577 (1876) (alteration in original).

58. See 39 Am. Jur. Nuisances, supra note 30 , $\$ 47$, at 332 . 
Villanova Law Review, Vol. 62, Iss. 4 [2017], Art. 2

trine of comparative injury." 59 Given the different phrasing, one might expect to find very different analytical processes taking place when each of these doctrines is invoked. Generally speaking, this does not seem to be the case ${ }^{60}$ Additionally, and perhaps most importantly, it was extremely common for courts to group together the terms, using them interchangeably to generally assert that a balancing analysis is available. ${ }^{61}$

Whatever phrasing American courts adopted, a common theme united jurisdictions: sharp limits on applying the balancing analysis. As a Florida court observed, "It is quite true that some of the states refuse to follow the doctrine of balancing the conveniences and others qualify it sharply." 62 A number of the cases generally observed that while balancing may be acceptable, it was also a doctrine to be applied "with great cau-

59. See, e.g., Heppenstall Co. v. Berkshire Chem. Co., 11 Conn. Supp. 82, 91 (Super. Ct. 1942) ("Entangled in every case involving a nuisance is the problem of weighing conflicting interests that are often most difficult to evaluate. The process has been called the doctrine of 'balancing interests' or 'balancing conveniences' or 'comparison of injuries' or 'balancing hardships.'”).

60. Instead courts are regularly using the doctrines interchangeably and using multiple phrases simultaneously. See Holman v. Athens Empire Laundry Co., 100 S.E. 207, 213 (Ga. 1919) (noting that injunctive relief is denied through balancing referred to as either "the balance of injury" or the "public benefit" or the "discretionary" doctrine); Sam Warren \& Son Stone Co. v. Gruesser, 209 S.W.2d 817, 820 (Ky. Ct. App. 1948) (noting party "invokes the doctrine of balance of interests," or as it is sometimes called "the balance of conveniences"); Carr's Beach Amusement Co. v. Annapolis Rds. Prop. Owners Ass'n, 160 A.2d 598, 599 (Md. 1960) (noting that "principle of balancing conveniences and inconveniences" is now sometimes referred to "in terms of the gravity of the harm weighed against the utility of the activity causing the harm"); Estancias Dall. Corp. v. Schultz, 500 S.W.2d 217, 219 (Tex. Civ. App. 1973) (equating doctrine of comparative injury and balancing of equities). Despite some effort looking specifically at each of these doctrines, my research did not show that each one represented a notably different approach. More than that, I primarily saw a historical progression in terminology. The doctrine of comparative injury was commonly referenced in older cases, but today it is rarely used, even though balancing analyses are much more common in modern cases.

61. See, e.g., Vowinckel v. N. Clark \& Sons, 13 P.2d 733, 736 (Cal. 1932) (equating doctrine of comparative injuries and balance of hardship); Hennessy v. Carmony, 25 A. 374,378 (N.J. Ch. 1892) (describing together "de mini[mi]s" and "balance of injury" inquiries); Davis v. Palmetto Quarries Co., 48 S.E.2d 329, 331 (S.C. 1948) (noting question of balance of convenience and then stating that it is also "called the "doctrine of comparative injury" (quoting Williams v. Haile Gold Mining Co., 66 S.E. 117 (1909))); Storey v. Cent. Hide \& Rendering Co., 226 S.W.2d 615, 618-19 (Tex. 1950) (noting application of "the doctrine of "comparative injury' or 'balancing of equities'"); Mitchell v. City of Temple, 152 S.W.2d 1116, 1117 (Tex. Civ. App. 1941) (considering "the question of comparative injury or 'balancing of the equities'"). omitted).

62. See Milling v. Berg, 104 So. 2d 658, 663 (Fla. Dist. Ct. App. 1958) (citation 
tion." 63 This caution seemed to be even further amplified if there was any potential of injury to the health of the plaintiffs. ${ }^{64}$

This cautious approach also appeared in cases, indicating that balancing was really only appropriate for circumstances in which the proof of nuisance is flawed or inadequate. Thus, some courts noted that balancing is not appropriate where the facts are "clearly established." 65 Courts reasoned that the rule of balancing "is not applied where the existence of a private right and the violation of it are clear." 66 In some of these cases, the real problem was that the proof of a significant harm, generally required for nuisances, may have been missing. Thus, the California Court of Appeals was able to say, "When an injunction to restrain a nuisance will produce great public or private mischief, a court of equity is not bound to grant it merely for the purpose of protecting a technical unsubstantial right." ${ }^{67}$ The court was concerned that injunctions should be limited to those instances when they remedy "some material injury to plaintiffs." 68 Through such adoptions of caution, courts in the early twentieth century frequently found ways to limit the idea of balancing generally.

More importantly, however, early twentieth century courts adopted a number of specific limits on balancing as a method of sharply limiting the application of the doctrine. The following sections discuss some of these specific limitations and their combinations.

\section{A. Damages a Matter of Right and Balancing Limited to Injunctions}

Traditionally, courts granted damages as "a matter of absolute right where the injury is shown." 69 Thus, even if the plaintiff was unable to obtain an injunction from the court, the plaintiff always traditionally still

63. See Ritz v. Woman's Club of Charleston, 173 S.E. 564, 565 (W. Va. 1934). Other courts note that "the "comparative injury" doctrine should be applied with great caution in nuisance cases." Bd. Of Comm'rs v. Elm Grove Mining Co., 9 S.E.2d 813, 817 (W. Va. 1940) (internal quotation omitted).

64. See Elm Grove Mining Co., 9 S.E.2d at 817.

65. See Morgan v. Zuckerman, 23 Pa. D. \& C. 199, 204 (York Cty. Ct. Com. Pl. 1935). A virtually identical rule was put forth in Krocker $v$. Westmoreland Planing Mill Co., 117 A. 669, 670-71 (Pa. 1922).

66. See Rosehill Cemetery Co. v. City of Chicago, 185 N.E. 170, 177 (Ill. 1933); see also Shaw v. Queen City Forging Co., 10 Ohio Dec. 107, 113 (Super. Ct. 1900) (citing H.G. WoOd, The Law OF Nuisances $§ 802$, at 1103 (3d ed. 1893) with nearly identical language).

67. Baldocchi v. Four Fifty Sutter Corp., 18 P.2d 682, 687 (Cal. Ct. App. 1933) (quoting Frost v. City of Los Angeles, 183 P. 342, 346 (Cal. 1919)). 1930)).

68. See id. (quoting Thompson v. Kraft Cheese Co., 291 P. 204, 208 (Cal.

69. See Collier v. City of Memphis, 4 Tenn. App. 322, 333-34 (1927). A balancing analysis is not a part of the damages analysis: "In estimating damage, the law will [not] undertake to balance conveniences or estimate the difference between the injuries sustained by the plaintiff and loss which may result to the defendant from having his business declared a nuisance." See Ingram v. City of Gridley, 224 P.2d 798, 801 (Cal. Dist. Ct. App. 1950) (citation omitted). 
Villanova Law Review, Vol. 62, Iss. 4 [2017], Art. 2

had a remedy at law. ${ }^{70}$ The rule simply was that the court could, in its "sound discretion, refuse the injunction and leave the complainant to his remedy at law." 71 In other words, courts wanted plaintiffs to always have a right of damages upon proving that a nuisance existed.

Courts also utilized their idea of adequate compensation as a condition for the availability of balancing tests in an injunction inquiry. Courts specifically limited the balancing test for an injunction to those circumstances where the injury "was such as to be capable of adequate compensation at law." 72 If the "damages [we]re of a nature which cannot be adequately compensated for in an action at law," then the courts would grant injunctions. ${ }^{73}$ In such cases the courts refused to "balance public benefits or public inconvenience against the individual right." 74 As the Michigan Supreme Court stated it, the rule was that " $[\mathrm{t}]$ he doctrine of 'comparative injury' should be confined to those situations where the plaintiff can be substantially compensated." 75

The point of a rule of full damages compensation before allowing balancing was to limit the discretion that a court would ordinarily have when considering an injunction request. Normally, the process of granting an injunction is one that involves discretion and a consideration of the equities. ${ }^{76}$ An injunction determination involves a balance of rights between private parties, ${ }^{77}$ and for this reason, many courts have refused to grant injunctions as a matter of right within nuisance cases. ${ }^{78}$ The common rule applied in nuisance cases is the general one for injunctions: "[A]n injunction is not a remedy which issues as [a matter] of course."79

70. See Mobile \& M. Ry. Co. v. Ala. M. Ry. Co., 23 So. 57, 58 (Ala. 1896) ("The bill, notwithstanding it presented a case where the court might grant the relief, was deemed not to be a proper one for injunction, but one in which the complainant should be left to the assertion of its legal rights in a court of law.").

71. See Hennessy v. Carmony, 25 A. 374, 378 (N.J. Ch. 1892) (emphasis added).

72. See Evans v. Reading Chem. \& Fertilizing Co., 28 A. 702, 711 (Pa. 1894).

73. See Wente v. Commonwealth Fuel Co., 83 N.E. 1049, 1052 (Ill. 1908).

74. See id.; see also Wheeler v. McIntyre, 175 P. 892, 895 (Mont. 1918) (finding that practice of weighing damages "should be resorted to only when the party whose substantial rights are threatened with invasion or destruction can be thoroughly protected.").

75. See Stream Control Comm'n v. City of Port Huron, 9 N.W.2d 41, 43 (Mich. 1943).

76. See Heppenstall Co. v. Berkshire Chem. Co., 11 Conn. Supp. 82, 92 (Super. Ct. 1942) ("The doctrine of balancing interests is well ingrained in equity procedure, although many of the courts which actually apply it refuse to admit it is a part of their practice.").

77. See John Norton Pomeroy, Pomeroy's Equity Jurisprudence and EQuiTABLE Remedies $§ 1944$, at 4414-16 (2d ed. 1919).

78. See Riter v. Keokuk Electro-Metals Co., 82 N.W.2d 151, 160-61 (Iowa 1957). But see Holman v. Athens Empire Laundry Co., 100 S.E. 207, 214 (Ga. 1919) ("The weight of authority is to the effect that at the final trial the right to injunctive relief is not discretionary.").

79. City of Harrisonville v. W.S. Dickey Clay Mfg. Co., 289 U.S. 334, 337-38 (1933) (alteration in original). 
While this general idea of discretion for injunctions in nuisance actions was common in the early twentieth century, courts also expressed concern over whether so much discretionary authority was appropriate in cases involving property rights. There was some natural appeal, perhaps, to the idea of courts having discretion that could be fitted to the circumstances of the case before them; however, there were also historical reasons to question the reasonableness of giving courts wide discretion, particularly when it came to property rights. As the Supreme Court of California observed, the idea of injunctions granted in equity had their "origin in an age when kings dispensed their royal favors." ${ }^{80}$ The court concluded that such an idea of grace or discretion "has no rightful place in the jurisprudence of a free commonwealth, and ought to be relegated to the age in which it was appropriate." 81 Granted, the court noted, "no chancellor ... will at this day admit that he dispenses favors or refuses rightful demands." 82 Still, the court embraced a rule that focused on the finding of a nuisance-not allowing a later option to balance. ${ }^{83}$ The court concluded that it was "enough to observe that [the doctrine of discretion/ grace] has no application where the act complained of is in itself, as well as in its incidents, tortious. In such cases it cannot be said that injury would result from an injunction." ${ }^{84}$ The Supreme Court of California was not inclined to allow general discretion where the consequences so immediately impacted an established property right.

\section{B. Limiting Balancing to Prospective and Preliminary Injunctions}

Some courts went much further than just limiting balancing to injunctions and indeed limited balancing to only preliminary or prospective injunctions, not final ones. In this context, the Supreme Court of South Carolina considered the prima facie showing, as well as the "balance of inconvenience on either side" before granting or denying an injunction. ${ }^{85}$ The question was whether "granting the injunctive relief work[ed] a greater hardship and greater injury upon the public than would result to the plaintiff by its denial." 86

Courts commonly limited such inquiries to the preliminary injunction stage. A Pennsylvania court, for example, concluded that balancing was

80. See Hulbert v. Cal. Portland Cement Co., 118 P. 928, 931 (Cal. 1911).

81. See id.

82. See id.

83. See id. at 931-32.

84. See id. at 932.

85. See Kennerty v. Etiwan Phosphate Co., 17 S.C. 411, 417 (1882) (emphasis omitted).

86. Mitchell v. City of Temple, 152 S.W.2d 1116, 1117 (Tex. Civ. App. 1941). The California District Court of Appeal used a similar approach in Wilms v. Hand, 226 P.2d 728, 731 (Cal. Dist. Ct. App. 1951) (noting duty of court to "balance the hardships" when issuing preliminary injunction). 
Villanova Law Review, Vol. 62, Iss. 4 [2017], Art. 2

only appropriate "when a preliminary injunction [was] sought." 87 When a final injunction was sought, and the "right [was] clear," the court found that "a refusal of an injunction, upon the ground that plaintiff cannot suffer as great a loss from the continuance of the nuisance as defendant would from interdiction, would be as far removed from equity as can be." 88 The general rule in these jurisdictions was that "[s]o far as the "balance of injury' notion refers to the parties of the litigation, it is pointed out ... that its legitimate application is to motions for preliminary injunctions, not to final decrees." 89

In granting a prospective injunction in a nuisance action, a court refused the injunction where "upon balancing the inconveniences or injuries, greater injury [would] be inflicted by granting than by refusing an injunction," 90 but refused to consider balancing "on final hearing." 91 The rule in these jurisdictions was that consideration could be given to the hardships worked on the defendant or the public "upon preliminary or interlocutory applications, but not upon final hearing." 92

\section{Equitable Balancing Limited to Public Necessity and Public Rights}

Particularly in older environmental cases, courts were at times moved to balance the injury to the private party against the many public benefits that accrued from the operation of mines and the like. Such benefits included not only employment and tax bases but also the products, such as copper or iron, that were publicly necessary. In some cases, courts denied injunctions due to the severity of the detriments to the public if the mines or plants were closed. ${ }^{93}$ Such industries, while problematic, could also be "the basic, sustaining industry of the community." ${ }^{4}$

These environmental cases raised the issue of whether and how to consider the impact on the public of issuing an injunction that might close an important business. On this issue, courts reasoned that when acting in equity, the court should not "remedy a wrong committed against one class

87. See Crew v. Gallagher, 58 Pa. D. \& C. 226, 243 (Chester Cty. Ct. Com. Pl. 1946), rev'd, 58 A.2d 179 (Pa. 1948).

88. See id. at 243 (quoting Evans v. Reading Chem. \& Fertilizing Co., 28 A. 702 (Pa. 1894)).

89. See United States v. Luce, 141 F. 385, 416 (Cir. Ct. D. Del. 1905) (citation omitted).

90. See Steiner v. Hennon, 17 Ohio Dec. 585, 589 (Allen Cty. Ct. Com. Pl. 1907); see also Maddox v. Willis, 54 S.E.2d 632, 638 (Ga. 1949) ("In an application for an interlocutory injunction there should be a balancing of conveniences and a consideration of whether greater harm might be done by refusing than by granting the injunction." (citations omitted)).

91. See Benton v. Kernan, 13 A.2d 825, 842 (N.J. Ch. 1940).

92. See Krebs v. Hermann, 6 P.2d 907, 910 (Colo. 1931).

93. See Bliss v. Anaconda Copper Mining Co., 167 F. 342, 371 (Cir. Ct. D. Mont. 1909) (discussing drastic consequences on the general public that would result from injunction); see also McCarthy v. Bunker Hill \& Sullivan Mining \& Concentrating Co., 164 F. 927, 940 (9th Cir. 1908) (same).

94. See Harless v. Workman, 114 S.E.2d 548, 552 (W. Va. 1960). 
of persons by the commission of another wrong against a larger class."95 The overall rule then became that "if it is found that the greater number would suffer injury by the allowance of such relief [an injunction] than the number of those that would be benefited by granting it, then the minority must yield to the majority and relief by abatement be denied."96 In some instances, courts reasoned, the detriments caused by a nuisance could be "more than balanced by the public benefits." 97 When the courts balanced, then, what they were looking for was adding a consideration of the "interests of the public good."98 The idea was that as with "so many questions in the law," the court needed to consider "the needs of trade and the rights of citizens."99 Balancing was accepted in these cases, with the limitation that the question must be one that was "affected by a public interest." 100

The idea of necessity played a substantial role in courts accepting the idea of balancing the public interest when deciding whether to issue an injunction to abate a nuisance. Some courts reasoned that the private individual has to give way when there was a clash with "the necessities of a great public industry." 101 The idea was that "[t] hose cases in which a nuisance is permitted to exist, under the rule of balancing rights . . . are based on the stern rule of necessity rather than on the right of the author of the nuisance to use his property in such a manner as to work a hurt or injury

95. See Fields Sewerage Co. v. Bishop, 30 S.W.2d 412, 415 (Tex. Civ. App. 1930). The Fields Sewerage case involved the provision of sanitation services to the citizens of a particular community, where the injury resulted from the operation of a sewerage plant. See id. In this particular instance, the court reasoned that " $[\mathrm{t}]$ he exercise of such power would be attended with the infliction of as great a wrong upon a much larger number of citizens. Under such a condition, appellees would be remitted to a suit for damages for compensation because of the injuries inflicted upon them." See id.

96. See id.

97. See New York v. Transit Dev. Co., 115 N.Y.S. 297, 304 (App. Div. 1909) (quoting New York v. Horton, 64 N.Y. 610, 620 (1876)). Notably, a number of these cases actually involve situations where the detriments of the alleged nuisance would fall to the public rather than to a private citizen. For example, the erection of a wharf could impede transportation for all citizens but also provide those citizens with "countervailing benefits," thus, the court would find that "if the public advantage greatly overbalance[d] any slight inconvenience that may be produced, it is no nuisance." See Pilcher v. Hart, 20 Tenn. 524, 533 (1840). The Pilcher case is remarkable for the finding that it is "no nuisance" (as opposed to finding a nuisance, but refusing an injunction), but the holding can be highly qualified here by the fact that the damages fell to the public as a whole (for interference with a public easement), rather than really to one private land owner. See id.

98. See Gray v. Grand Trunk W. R.R. Co., 91 N.W.2d 828, 834 (Mich. 1958).

99. See L.D. Pearson \& Son v. Bonnie, 272 S.W. 375, 377 (Ky. 1925). But see City of Harrisonville v. W.S. Dickey Clay Mfg. Co., 289 U.S. 334, 338 (1933) (noting that balancing may be accepted by court "even if the conflict is between interests which are primarily private").

100. See Huebschmann v. Grand Co., 172 A. 227, 230 (Md. 1934).

101. See Pennsylvania v. Phila. \& Reading Coal \& Iron Co., 50 Pa. D. \& C. 411, 417 (Phila. Cty. Ct. Com. Pl. 1944) (citation omitted). 
Villanova Law Review, Vol. 62, Iss. 4 [2017], Art. 2

to his neighbor."102 Courts also were sympathetic to business owners who operated their facilities to the best of their ability while generating a necessary product-in other words, some businesses, no matter how cleanly and carefully operated, generate negative externalities. As the Supreme Court of Appeals of West Virginia explained regarding a mine, "[A] problem of coal dust to at least some degree is inevitable wherever coal is mined, processed, handled, and transported."103

The Iowa Supreme Court issued what may be the strongest formulation of the rule of considering public benefits. ${ }^{104}$ The Iowa Supreme Court faced a case in which the alleged nuisance was caused by "a public service corporation furnishing light and power to the public"; notably, the corporation could not "abandon its public service without consent of the public service commission."105 In these circumstances, the Iowa Supreme Court found that an "injunction would be proper only under extreme circumstances."106

Finally, even while courts have been willing to consider public benefits when contemplating an injunction, there still seems to be strong limits to this position. In short, even substantial public benefits have not always been sufficient for courts to deny an injunction. In a number of similar cases, the defendants argued for a balancing of the injuries, but the courts still granted injunctions against the company defendant. ${ }^{107}$ The problem, for some courts, was that " $[\mathrm{t}]$ he violation of a public right enjoyed by a portion of the community is not justified by offsetting an advantage accruing to others." 108

Additionally, when courts balanced the public interest against the damage to the plaintiff-neighbor of the nuisance, another limiting doctrine came into play: the courts carefully noted that not all injunctions, 1930).

102. See Fields Sewerage Co. v. Bishop, 30 S.W.2d 412, 415 (Tex. Civ. App.

103. See Harless v. Workman, 114 S.E.2d 548, 552 (W. Va. 1960).

104. See Friedman v. Forest City, 30 N.W.2d 752, 757 (Iowa 1948).

105. See id. (quoting Byrne v. Monongahela W. Penn Pub. Serv. Co., 146 S.E. 522, 524 (W. Va. 1929)).

106. See id.

107. See, e.g., Georgia v. Tenn. Copper Co., 206 U.S. 230 (1907); Am. Smelting \& Ref Co. v. Godfrey, 158 F. 225, 241 (8th Cir. 1907); Arizona v. Smelting \& Lead Co., 124 P. 692 (Cal. 1912); Arizona Copper Co. v. Gillespie, 100 P. 465, 471 (Ariz. 1909).

108. See Conn. River Lumber Co. v. Olcott Falls Co., 21 A. 1090, 1094 (N.H. 1889). The Supreme Court of New Hampshire observed that this type of balancing of public advantages and disadvantages was a task better suited to the legislature than to the courts. See id. at 1095. Another reason that courts have granted injunctions is that often these businesses, while providing a public benefit, also create detriments to public health. In such instances a court might conclude that if "it is shown by facts and circumstances to constitute a nuisance affecting public health "no measure of necessity, usefulness or public benefit will protect it from the unflinching condemnation of the law." Bd. of Comm'rs v. Elm Grove Mining Co., 9 S.E.2d 813, 817(W. Va. 1940) (quoting Horace G. Wood, The Law of NuISANCES, § 19, at 40-43 (3d ed. 1893)). 
not even all injunctions that required abatement of a nuisance, necessarily meant shutting down the operations of a business. In other words, injunctions are devices that allow for a spectrum of solutions and need not be just binary (grant or deny) decisions. Instead, one of the options that the court has is to find ways that the business can still provide its services, while at the same time limiting or removing the ongoing nuisance through some change in operations and expenditure of funds. Thus, for example, an injunction might be granted where the court found on the evidence that a change could be made "at a cost apparently not prohibitory, but means of which full relief is granted" to the plaintiffs while services continue for the public. ${ }^{109}$

Notably, even in the circumstances where courts were willing to balance harms to the public and then potentially refuse to grant injunctions, this did not mean that the plaintiff was left entirely without a remedy. In such cases, the courts still made available to the plaintiff his or her legal remedies, including damages. ${ }^{110}$

Finally, some courts explicitly rejected the public interest as a justification for entering into a balancing analysis when considering whether to issue an injunction. The Supreme Court of Appeals of West Virginia reasoned that "the fact that the primary purpose of defendant is to serve the public does not alter the situation." 111 The problem was that "it would be manifestly unfair to require plaintiffs to bear all the ill-effects of this nuisance, merely that the public might benefit indirectly." 112 In considering this case, the Supreme Court of Appeals of West Virginia then directly connected the problem to a takings claim, noting that "the Constitution itself forbids injury to private property for a public purpose without just compensation."113 Consequently, the court concluded, because there was no compensation for the nuisance, it could not matter that the public would lose some benefits by abating the nuisance. ${ }^{114}$ Summarizing this rule, one Ohio court explained that while the nuisance might be "convenient and useful to the public," provided that the nuisance was proven, then the benefit to the public "furnishe[d] no defense whatever."115 1930).

109. See Fields Sewerage Co. v. Bishop, 30 S.W.2d 412, 415 (Tex. Civ. App.

110. See id.

111. See Ritz v. Woman's Club of Charleston, 173 S.E. 564, 565-66 (W. Va. 1934).

112. See id.

113. See id. at 566.

114. See id.

115. See Brown v. Village of St. Bernard, 20 Ohio Dec. 422, 426 (Hamilton Cty. Ct. Com. Pl. 1910) (quoting H.G. Wood, The Law of Nuisances, § 75, at 104 (3d ed. 1893)). 
Villanova Law Review, Vol. 62, Iss. 4 [2017], Art. 2

\section{Balancing Really Means Addressing De Minimis Advantages}

In some jurisdictions, when courts speak of balancing in the nuisance analysis, the inquiry is not one of weighing competing interests but rather the much simpler question of whether the advantages accruing to the landowner from granting the injunction would be de minimis. ${ }^{116}$ The idea here is that an injunction should be denied "where the injury to the complainant by the continuance of the nuisance is small, and the injury to the defendant by its discontinuance is great." 117 Courts have refused to issue injunctions where doing so "[would] cause great injury to defendant, and [would] confer no benefit or very little benefit in comparison upon complainant." 118

More generally, when courts say balance, they do not mean a slight tipping of the scales. Instead, the courts seem to be looking for a strong tilt in one direction. In other words, while the action of the court in making a judgment is referred to as simply balancing, what the court is really doing is searching for a "disproportionate hardship." In City of Harrisonville v. W.S. Dickey Clay Manufacturing Co., ${ }^{119}$ the United States Supreme Court incorporated this approach, requiring a finding of not only a disproportionate hardship but even a "grossly disproportionate hardship."120 Courts applied this approach where granting an injunction would "work an undue hardship on the defendant without corresponding benefit to the plaintiff and substantial redress [could] be afforded by the payment of money." 121 The idea here was that "equity may sanction the denial of injunctive relief when such relief would cause damage greatly disproportionate to the injury sought to be redressed." ${ }^{122}$ Rules like these ensured that when courts balanced, the real inquiry was not a general measure of weights but rather a tough look for a disproportionate outcome. This significantly limited the balancing test as applied.

\section{E. Balancing Granted in the Event of Laches}

In some cases, defendants have argued not that they are entitled to a balancing test generally, but rather that they are entitled to that balancing specifically because the plaintiff has engaged in laches. In such cases, as a

116. See Hennessy v. Carmony, 25 A. 374, 378 (N.J. Ch. 1892).

117. See id. (emphasis added).

118. See Sam Warren \& Son Stone Co. v. Gruesser, 209 S.W.2d 817, 820 (Ky. Ct. App. 1948).

119. 289 U.S. 334 (1933).

120. See id. at 338.

121. See Sam Warren E Son Stone Co., 209 S.W.2d at 820. The corresponding benefit idea occurs regularly in the nuisance case law. For example, the Supreme Court of Oregon found that an injunction should be refused where "the issuance of an injunction would cause serious public inconvenience or loss without a correspondingly great advantage to the complainant." Fraser v. City of Portland, $158 \mathrm{P}$. 514, 516 (Or. 1916). 1973)

122. See Villalon v. Town of Westport, 317 A.2d 155, 158-59 (Conn. Super. Ct. 
result of laches, the plaintiff has been "standing by until after [the] defendant has expended a large sum of money." 123 Some courts have supported this position and allowed laches to be grounds for invoking a balancing analysis in the injunction question. This position aligns with the Restatement (First) of Torts' position generally on injunctions, which finds that one of the things to be considered is "plaintiff's delay in bringing suit." ${ }^{24}$ Under this theory, laches is not an "absolute defense," but rather one of the "matters of equitable consideration" for the court. ${ }^{125}$ In these jurisdictions, courts could limit balancing to circumstances where the plaintiff had already done the defendant a disservice through unreasonable delay.

\section{F. Combining Strict Restrictions on Balancing for Greater Limits}

Commonly, courts incorporated more than one of these limits on the balancing test. In 1915, Pomeroy's Equity Jurisprudence and Equitable Remedies noted "where the damages can be measured and compensated, equity will not interfere where the public benefit greatly outweighs private and individual inconvenience." 126 Looking carefully at this position, Pomeroy's position requires (1) that damages are measurable, (2) damages can adequately compensate for the damage, (3) a strong public benefit that will outweigh, and (4) that the other side is a private or individual inconvenience as opposed to a public one. ${ }^{127}$

In W.S. Dickey Clay Manufacturing Co., the United States Supreme Court incorporated a similar position. The Court reasoned that " $[\mathrm{w}]$ here substantial redress can be afforded by the payment of money and issuance of an injunction would subject the defendant to grossly disproportionate hardship, equitable relief may be denied although the nuisance is indisputable." 128 Notably, the Court not only embraced the two limitations (redress by damages and disproportionate hardship), the court also left the decision as discretionary, finding that relief "may be denied." 129

One common combination of restrictions was that of balancing only for preliminary injunctions and only where there was a public interest in the outcome. Thus, requests for preliminary injunctions could also be limited by only considering a balance between the harm to the plaintiff and public interests rather than the interests of private party defendants. The question was whether "granting the injunctive relief work[ed] a

123. See Pomeroy, supra note $77, \S 1944$, at 4419 n.15.

124. See Restatement (First) of Torts $§ 939$ (Am. Law Inst. 1939).

125. See Hughes v. Jones, 94 S.W.2d 534, 536 (Tex. Civ. App. 1936).

126. See Pomeroy, supra note 77, § 1945.

127. See id. $§ 1945$, at 4419-23.

128. See City of Harrisonville, 289 U.S. at 338.

129. See id. 
Villanova Law Review, Vol. 62, Iss. 4 [2017], Art. 2

greater hardship and greater injury upon the public than would result to the plaintiff by its denial." 130

Courts also combined the de minimis limitation with other limits. Limitations included whether "the right [was] doubtful" or that "money damages [would] compensate the plaintiff," or that there was some other method of otherwise redressing the wrong. ${ }^{131}$ Additionally, courts limited the idea of balancing benefits to the public by looking for something that appeared to be de minimis on the other side. In other words, the situation was not just that there were strong public benefits but also that in comparison to those benefits, there was a "trifling inconvenience" of the private individual. ${ }^{132}$ Some courts, rather than looking only for de minimis benefits on the plaintiff's side, looked more generally to the proportionality between the detriments and the benefits in cases that involve an inconvenience to the public. ${ }^{133}$

Such combinations of limits also fit with contemporary treatises that combined limits on balancing. H.G. Wood's The Law of Nuisances supported balancing, but in a very limited fashion. The Law of Nuisances focused first on limiting its advice to those cases before a court of equity. ${ }^{134}$ Within the context of a court of equity, Wood focused on the special role of that court, whose "true intent" Wood believed to be "do[ing] justice between the parties."135 As a result, Wood found that an injunction was only appropriate "where the rights of the parties demand it." ${ }^{36}$ To determine that, Wood found that the courts should look to "all the circumstances of the location, the effect of the act claimed to be a nuisance, and the effect upon the defendant's business and interests." 137 Notably, Wood discussed these limitations in the context of a case that involved a claim of laches on the part of the plaintiff. ${ }^{138}$ Even in this circumstance, Wood cautioned that the "usefulness of the business, or its importance, magnitude or extent" would not prevent an injunction from issuing. ${ }^{139}$ Thus, what Wood proposed was not simple balancing and looking for a bare tip of the scales.

Instead, Wood noted that refusing to issue an injunction would require that the injury be "small and fairly compensable in damages" while in contrast the "damages and loss to the other party would be large and

130. See Mitchell v. City of Temple, 152 S.W.2d 1116, 1117 (Tex. Civ. App. 1941) (emphasis added).

131. See Sam Warren \& Son Stone Co. v. Gruesser, 209 S.W.2d 817, 820 (Ky. Ct. App. 1948).

132. See Pennsylvania v. Phila. \& Reading Coal \& Iron Co., 50 Pa. D. \& C. 411, 417 (Phila. Cty. Ct. Com. Pl. 1944) (emphasis omitted).

133. See Fraser v. City of Portland, 158 P. 514, 516 (Or. 1916).

134. See H.G. Wood, The Law of Nuisances $§ 801$, at 1176 (3d ed. 1893).

135. See id. § 801, at 1182.

136. See id.

137. See id.

138. See id.

139. See id. 
disastrous." 140 Therefore, the court would have to make two distinct findings: (1) that the plaintiff's injuries were quite minor, perhaps de minimis, and (2) that the plaintiff could be fully compensated by damages. Wood concluded by noting that the denial of the injunction would not result in sending away the plaintiff without remedy-only that the plaintiff would be left to his legal remedy of damages. ${ }^{141}$ Most importantly, Wood did not appear to consider balancing within the context of an action for damages. Instead: "The law does not, however, balance conveniences, and it makes no difference if the work is really in the interest of society, or necessary for the preservation of the public health." 142

\section{The Revisionist Trend And the Power of Balancing}

In general, courts frequently recognized that the doctrines of nuisance, both in terms of the prima facie case and the remedies rules, are confused and conflicting, even within individual jurisdictions. As the Iowa Supreme Court observed in 1957, "There is considerable conflict among decisions as to the basic doctrine and various elements thereof and exceptions thereto." 143

This confusion escalated with the unification of courts of equity and courts of law through the twentieth century. As the Restatement (First) of Torts explained, "A potent cause of confusion as to the meaning and scope of private nuisance lies in the failure to distinguish the action at law from the suit for injunction in equity. Cases in equity are cited as precedents in actions at law without regard to their differences." 144 This is particularly important because, as the Restatement (First) of Torts observes, "considerations enter into the determination of the right to an injunction that are inapplicable or have less weight in determining the right to damages." 145 Such mingling of equity jurisprudence with thought about the prima facie case for nuisance may well have caused much of the shift in nuisance law during the modern era.

This process of conflating equity and law explains how a doctrine once limited to an equitable remedy could migrate into the prima facie case of nuisance. This section focuses on the substantial changes that took place in the mid-to-late twentieth century: the movement of balancing into the prima facie case through the reasonableness element and the dropping of limitations on balancing.

140. See id.

141. See id.

142. Seacord v. People, 13 N.E. 194, 200 (Ill. 1887).

143. See Riter v. Keokuk Electro-Metals Co., 82 N.W.2d 151, 161 (Iowa 1957).

144. See Restatement (First) of Torts, supra note 124, at 223.

145. See id. at 224. 
Villanova Law Review, Vol. 62, Iss. 4 [2017], Art. 2

672

Villanova Law Review

[Vol. 62: p. 651

\section{A. Removing the Limits on Balancing}

Historically, one of the most significant limits on balancing was the requirement that courts consider the public interest-as opposed to the harms to the defendant. Courts from the 1950s forward moved away from the restriction on limiting balancing to concern about the public interest. These courts weighed not only the potential damage to the public from granting an injunction (a rarer occurrence) but also considered the potential damage to the private defendant from granting an injunction (a virtual certainty in any nuisance case). This was no small change for plaintiffs, who now must balance their property rights against the investments that the plaintiff may have made in a neighboring property that just happens to be worth more money.

The new rule became that the courts would consider "the injury which may result to the defendant" as well as the public from granting an injunction. ${ }^{146}$ Notably, after stating a rule that allows considering the damage to the defendant, the Supreme Court of Texas followed the rule with a discussion of the public interest and necessity. ${ }^{147}$ The court then concluded the discussion by embracing a rule that favored not just balancing public detriments but also any private detriment to the defendant, despite having not really addressed reasons for including private damage within the balancing test. ${ }^{148}$ Rather than weighing only the public interest, the court only considered the alternative argument of giving injunctions as a matter of right (an idea that the court dismissed as less favored). ${ }^{149}$ This case is indicative of the kind of soft reasoning that allowed courts to move from considering only the public interest to also considering the harms to private defendants.

Treatises, and particularly the Restatements, appeared to play a role in adopting balancing more generally and without limits. The Law of Torts by William L. Prosser concluded that " $[\mathrm{t}]$ he reasonableness of the interference is determined by weighing the gravity of the harm to the plaintiff against the utility of the defendant's conduct." ${ }^{150}$ A number of cases that adopted a weighing of utilities approach to reasonableness cited to Prosser

146. See Storey v. Cent. Hide \& Rendering Co., 226 S.W.2d 615, 619 (Tex. 1950); see also Fields Sewerage Co. v. Bishop, 30 S.W.2d 412, 415 (Tex. Civ. App. 1930) (holding that "[i]t is always the duty of the court to consider the inconvenience and damage that will result to the defendant . . . in all cases where a writ of injunction is sought.").

147. See Storey, 226 S.W.2d at 619.

148. See id.

149. See id. at 515. Notably, the Texas Court of Civil Appeals also moves the balancing test from being limited to temporary injunctions to being applicable to final injunctions as well. See Massengill v. Jones, 308 S.W.2d 535, 541 (Tex. Civ. App. 1957).

150. See William L. Prosser, Handbook of the Law of Torts $§ 72$, at 405 (2d ed. 1955). 
for this point. ${ }^{151}$ Notably, Prosser began with the historical definition of reasonableness-he noted that nuisance was about the conflict of one owner's right to use his land as she pleased with the other owner's right to be secure in not being bothered in his possession. ${ }^{152}$ Prosser then observed that " $[\mathrm{t}]$ he two are correlative and interdependent, and neither is entitled to prevail entirely, at the expense of the other." ${ }^{153}$ It was from this latter thought that Prosser moved to the idea of balancing as a solution to this dilemma, saying, "[s] ome balance must be struck between the two." 154

The Restatements also may have played a role in adopting the idea of balancing harms to the defendant and eschewing any limits on the doctrine. The Restatement (First) of Torts did not explicitly include balancing as a part of the prima facie case for nuisance; ${ }^{155}$ it did, however, include reasonableness as a part of the prima facie case. ${ }^{156}$ The balancing inquiry entered through the element of reasonableness because of how the Restatement (First) of Torts defined unreasonableness. The Restatement (First) of Torts declared that unreasonableness was determined in part by weighing the "utility of the actor's conduct" against "the gravity of the harm." 157 Most importantly, the Restatement (First) of Torts omitted one of the strongest historical limitations on balancing-the limitation of public interest or public necessity-by declaring that a part of the analysis was weighing not only the community interests but also the harms to the defendant- "the interests of the actor"-as well. ${ }^{158}$ In its strongest statement, the Restatement (First) of Torts urged that "determining unreasonableness is essentially a weighing process, involving a comparative evaluation of conflicting interests in various situations according to objective legal standards."159 The Restatement (First) of Torts focused heavily on balancing, making the heart of the unreasonableness analysis a weighing process ${ }^{160}$ - something it had

151. See Stockdale v. Agrico Chem. Co., 340 F. Supp. 244, 250 (N.D. Iowa 1972) (citing Prosser and finding that reasonableness is determined by weighing harm versus utility).

152. See Prosser, supra note $150, \S 72$, at $410-11$.

153. See id. $\S 72$, at 410 .

154. See id.

155. See Restatement (First) of Torts, supra note 124, § 822, at 226.

156. See id.

157. See id. \$ 826, at 241.

158. See id. $\$ 826 \mathrm{cmt}$. b, at 241-42. The Restatement (First) of Torts also acknowledged that law would place a "social value" on any type of use of land and that this should also be a part of the weighing of the gravity of harm to the defendant. See id. $\S 827$, at 244 . Similarly, social value was also given as a part of the weighing of utility of conduct. See id. $\$ 828$, at 250 . Notably, in this discussion, the Restatement (First) of Torts is limiting itself to a discussion of actions for damagesthe "[c] hapter does not state the rules that are peculiar to the determination of the right to an injunction." See id. at 215.

159. See id. $\$ 826 \mathrm{cmt}$. b, at 242.

160. See id. $\S 826 \mathrm{cmts}$. b-d, at 241-44 (describing reasonableness as "essentially a weighing process" and then extensively discussing the many ways of weighing gravity of harm and social utility within next two comments); see also Nair v. 
Villanova Law Review, Vol. 62, Iss. 4 [2017], Art. 2

not been historically. ${ }^{161}$ Cases adopted this perspective by citing the $R e^{-}$ statement (First) of Torts. ${ }^{162}$ The Restatement (First) of Torts approach of considering a wide variety of circumstances and weighing the conflicting interests became a standard approach of the courts by the 1950s and 1960s. ${ }^{163}$

Ultimately, a number of courts have shifted the idea of reasonableness, a key element of the nuisance inquiry, in such a way that the concept now includes a balancing of harms to the defendant as well as the community. ${ }^{164}$ As a result, for the plaintiff to even prove that a nuisance exists,

Thaw, 242 A.2d 757, 761 (Conn. 1968) (citing Restatement (First) of Torts and describing reasonableness as being centrally about weighing).

161. See supra notes 59-142 and accompanying text.

162. See Ming Li v. Colonial BT, LLC, No. 3:14-cv-999, 2015 WL 5684060, at *4 (D. Conn. Sept. 28, 2015) (finding that unreasonableness is determined by considering defendant's interests as well as those of community and citing Restatement (Second) of Torts); In re Methyl Tertiary Butyl Ether ("MTBE") Prods. Liab. Litig., 824 F. Supp. 2d 524, 537 (S.D.N.Y. 2011) ("It is substantial if it causes significant harm and unreasonable if its social utility is outweighed by the gravity of the harm inflicted." (citation omitted)); Rudd v. Electrolux Corp., 982 F. Supp. 355, 369 (M.D.N.C. 1997) ("The touchstone is reasonableness where the social utility of defendants' use is balanced against the harm and interference with plaintiff's use of her property." (citation omitted)); Pub. Serv. Co. of Colo. v. Van Wyk, 27 P.3d 377, 391 (Colo. 2001) (finding that reasonableness requires weighing gravity of harm and utility of conduct and citing Restatement (Second) of Torts); Radziewicz v. Frankenmuth, No. 282648, 2009 WL 2974733, at*1 (Mich. Ct. App. Sept. 17, 2009) (noting that unreasonableness is about weighing social utility and harms and citing Restatement (Second) of Torts); Clinic \& Hosp., Inc. v. McConnell, 236 S.W.2d 384, 391 (Mo. Ct. App. 1951) (noting the rule of reasonableness, including social value and utility in analysis and citing Restatement (Second) of Torts); Kopecky v. Nat'l Farms, Inc., 510 N.W.2d 41, 48 (Neb. 1994) (considering social utility as a part of the reasonableness analysis and citing the Restatement); Padilla v. Lawrence, 685 P.2d 964, 968 (N.M. Ct. App. 1984) (adopting the gravity of harm and utility of conduct approach to reasonableness and citing Restatement (Second) of Torts); Hale v. Ward Cty., 818 N.W.2d 697, 703 (N.D. 2012) (noting factors to be considered for reasonableness and adopting balancing of utility with the harm and citing Restatement (Second) of Torts); Hatch v. W.S. Hatch Co., 283 P.2d 217, 221 (Utah 1955) (finding that whether "an actionable nuisance exists must depend upon weighing the gravity of harm to the plaintiffs against the utility and reasonableness of defendants' conduct" (citing Restatement (First) of Torts, supra note $124, \S 40)$.

163. See Haczela v. City of Bridgeport, 299 F. Supp. 709, 711-12 (D. Conn. 1969) ("Determining reasonableness is essentially a weighing process, involving a comparative evaluation of conflicting interests in various situations according to objective legal standards." (citations omitted)); Wright v. Masonite, 237 F. Supp. 129, 137 (M.D.N.C. 1965) (finding that reasonableness is about considering not only interests of defendants, but also those of communities); In re Bloomingdale Partners, 160 B.R. 101, 109 (Bankr. N.D. Ill. 1993) (finding that unreasonableness is measured by considering social utility of the defendant's business); Kitsap Cty. v. Kitsap Rifle \& Revolver Club, 337 P.3d 328, 399 (Wash. Ct. App. 2014) (noting that reasonableness is determined by weighing harm to plaintiff and social utility of defendant's business).

164. See Walsh v. Town of Stonington Water Pollution Control Auth., 736 A.2d 811, 819 (Conn. 1999) (applying social utility balancing approach as part of reasonableness analysis in prima facie case); Walker v. Williams, No. 9667-VCG, 
Fraley: The Uncompensated Takings of Nuisance Law

the plaintiff must establish that the harm outweighs the utility of the defendant's use to the community as well as any harms to the defendant personally. Such a balance may be naturally difficult to win where the defendant is operating a business that has any use at all to the community or if the defendant would suffer any substantial harm by removing the offending use. ${ }^{165}$

\section{B. Balancing in the Prima Facie Case Through Reasonableness}

One of the most important transformations of nuisance law has been the movement of the balancing test from the remedies analysis to the prima facie case-meaning that damages were always available without passing a balancing test even if injunctions were not. When balancing moves into the prima facie case, it means that balancing could prevent there ever being a finding of nuisance, thus denying the plaintiff all remedies. ${ }^{166}$ Balancing moved into the prima facie case primarily through the element of reasonableness. In this section, I discuss in detail the expansion of reasonableness and the movement of the balancing test into the prima facie case for nuisance. In the next part, I consider the theoretical implications of this transformation of doctrine.

The redefinition of reasonableness was significant for a few reasons. First, by redefining reasonableness, courts moved the balancing inquiry from the remedies phase of litigation into the initial question of whether a nuisance exists. Second, by redefining reasonableness, courts made this substantial shift-one that Lewin described as reducing the scope of nuisance actions-without any obvious change to the elements of the prima facie case. ${ }^{167}$ Third, such a change did not take a great deal of effort in many ways. Reasonableness, allowing for an examination of contexts, is

2016 LEXIS 91, at*19 (Del. Ch. June 23, 2016) (following reasonableness balancing test to determine if private nuisance existed); Birchwood Lakes Colony Club, Inc. v. Borough of Medford Lakes, 432 A.2d 525, 531-32 (N.J. Super. Ct. App. Div. 1981) (considering benefits to public health in social utility balancing approach to reasonableness); Whiteside Estates, Inc. v. Highlands Cove, L.L.C., 553 S.E.2d 431, 436 (N.C. Ct. App. 2001) (considering social utility of defendant's business in determining reasonableness).

165. Consider, for example, the recent case of Blue Ink, Ltd. v. Two Farms, Inc., where the Maryland Court of Special Appeals weighed the reasonableness of the interference with the utility of a convenience store available to the community. 96 A.3d 810, 820 (Md. Ct. Special App. 2014).

166. See Lewin, supra note 12, at 780. In Lewin's article on compensated injunctions, he briefly mentions that the element of reasonableness appears to be the mechanism that allows the balancing inquiry to become a primary part of the nuisance analysis. See id. Lewin concludes that this move "reduced the scope of the nuisance doctrine, enabling courts to find that certain interferences with the use and enjoyment of land were not actionable." See id. Despite making such a remarkable observation-and one that, I believe, is quite accurate-Lewin moved on to other topics rather than further discussing the evolution of the reasonableness element or considering how these changes might have had greater theoretical implications for property law. See id. at 780-81.

167. See id. at 780 . 
Villanova Law Review, Vol. 62, Iss. 4 [2017], Art. 2

676

Villanova Law Review

[Vol. 62: p. 651

rather amenable to expansion. Thus, courts in the 1950s could easily move between discussing the flexibility of reasonableness to including an idea of the balancing of the rights of the parties. This was particularly true because some of the early formulations of reasonableness already used the term "balance" but just did so in a way that did not include a weighing of harms or social utility.

With respect to this flexibility of reasonableness and the already existent idea of some sort of balance, the Washington Supreme Court's analysis of reasonableness provides a great example of how courts shifted the doctrine. The Washington Supreme Court stated that within the law of nuisance, "rights as to the usage of land are relative." 168 The court then explained that this relativity was primarily about when it was unreasonable to interfere with another landowner's use and enjoyment. ${ }^{169}$ After noting that "[t]he crux of the matter appears to be reasonableness," the court noted that the term "has many shades and varieties of meaning" and is always fitted "in relation to all the facts and surrounding circumstances." 170 The court then immediately observed that the application of nuisance law "requires a balancing of rights, interests, and convenience." 171 Balancing to determine reasonableness became the norm for Washington courts, where the rule became that the courts "determine the reasonableness of a defendant's conduct by weighing the harm to the aggrieved party against the social utility of the activity." 172

Throughout the twentieth century, American courts increasingly redefined reasonableness in a way that adopted the Restatement (First) of Torts perspective, described above, which included not only the social utility weighing, but also a consideration of the harms to the defendant. To determine "whether an actionable nuisance exist[ed]," courts weighed "the gravity of harm to the plaintiffs against the utility and reasonableness of the defendants' conduct." 173 This analysis did not just take place in the remedies phase, but instead, reasonableness was a part of "determining ... . the fact" of the existence of a nuisance. ${ }^{174}$

At times, courts adopted this perspective specifically to favor local industries. The Idaho Supreme Court reasoned that its state was "sparsely populated and its economy depend[ed] largely upon the benefits of agriculture, lumber, mining and industrial development. To eliminate the utility of conduct and other factors . . . to be considered in determining

168. See Morin v. Johnson, 300 P.2d 569, 572 (Wash. 1956).

169. See id.

170. See id.

171. See id.

172. See Kitsap Cty. v. Kitsap Rifle \& Revolver Club, 337 P.3d 328, 339 (Wash Ct. App. 2014) (quoting Lakey v. Pugent Sound Energy, Inc., 296 P.3d 860, 868 (Wash. 2012)).

173. See Hatch v. W.S. Hatch Co., 283 P.2d 217, 221 (Utah 1955).

174. See Graceland Corp. v. Consol. Laundries Corp., 7 A.D.2d 89, 92 (N.Y. App. Div. 1958). 
whether a nuisance exists . . . would place an unreasonable burden upon these industries." 175 The court specifically noted that it was embracing a definition of nuisance that included weighing these public interests in a suit that was seeking only damages and not an injunction. ${ }^{176}$

In 1942, a Connecticut Superior Court judge observed the sneakiness of including balancing as a part of the reasonableness analysis. The judge noted that while balancing was a normal part of equity procedure, many courts did not want to "admit it is a part of their practice." 177 Such courts instead "prefer[red] to base their conclusions on the ground that the use to the invader is not unreasonable under all the circumstances." 178 The judge then concluded: "[T]his is splitting hairs, because, fundamentally, the unreasonableness of an intentional invasion is a problem of relative values to be determined after giving due weight to all of the factors of each case." 179

V. Theoretical Implications of Balancing in Nuisance Doctrine and Modern Reconsiderations of Nuisance Law

\section{A. Balancing as Affecting a Taking}

Some scholars have connected nuisance law and takings claims in the context of recent right-to-farm statutes. ${ }^{180} \mathrm{I}$ argue here that there is no need to constrain our inquiry to the right-to-farm style statutes. There is ample evidence that the modern evolution of nuisance law- the sharp limitation of its scope through the introduction of (unlimited) balancing into the prima facie case-creates regulatory takings more generally within nuisance law.

Courts shared this concern throughout the first half of the twentieth century. Early courts regularly discussed the problem of takings in the context of nuisance law, particularly when courts were resisting the introduction of balancing tests or the removal of limits on those tests.

The Supreme Court of Illinois rejected the idea of thinking about social utility in the nuisance context because " $[\mathrm{t}]$ o hold otherwise would be to compel the citizen to abandon his property at the demand of public convenience, without the forms of law and without compensation." 181 The court further reasoned that a nuisance would compel the plaintiff to "submit to having their lives made physically uncomfortable, and their

175. See Carpenter v. Double R Cattle Co., 701 P.2d 222, 228 (Idaho 1985).

176. See id. at 229.

177. See Heppenstall Co. v. Berkshire Chem. Co., 11 Conn. Supp. 82, 91-92 (Super. Ct. 1942).

178. See id. at 92 .

179. See id.

180. See generally Terence J. Centner, Governments and Unconstitutional Takings: When Do Right-to-Farm Laws Go Too Far?, 33 B.C. EnvtL. Aff. L. Rev. 87 (2006) (arguing that state anti-nuisance laws, or right-to-farm laws allow nuisances to continue, creating regulatory takings).

181. See Seacord v. Illinois, 13 N.E. 194, 200-01 (Ill. 1887). 
homes made unenjoyable." ${ }^{82}$ This was unacceptable because, "[p]rivate property cannot be taken for public use without just compensation, and it can make little difference whether it is taken, or it is destroyed for the uses of civilized life." 183 The court further observed that, "It can make no difference that the convenience, or even the preservation of the health, of a large population ... or that the number actually injured by the nuisance is comparatively small." 184

Similarly, the Supreme Court of Appeals of West Virginia connected nuisance with takings, reasoning that "the Constitution itself forbids injury to private property for a public purpose without just compensation." 185 Consequently, the Supreme Court of Appeals of West Virginia concluded, because there is no compensation for the nuisance, it cannot matter that the public would lose some benefits by abating the nuisance. ${ }^{186}$

The Supreme Court of South Carolina agreed with this analysis. The court concluded that:

$[\mathrm{U}]$ nder the provisions of the Constitution of this State, that private property shall not be taken for private use without the consent of the owner, the court could not have considered, in deciding whether or grant or refuse the injunction, the question raised by the defendant as to the balance of convenience, or of advantage or disadvantage to the plaintiff and defendant and the public at large ....187

On the topic of social utility and balancing, the Supreme Court of Pennsylvania noted that it could not "find a case in which substantial injuries to property rights, to the rights of enjoying and possessing property, have been sanctioned by a final refusal to enjoin, on the mere ground that the public was interested in their continuance." 188 The problem in the end was that "the public usefulness of an enterprise is no reason why private right should be infringed." 189

Some courts felt so strongly about the takings problem that they refused to even dismiss those cases where the plaintiff's injury could easily be described as de minimis. Their reasoning was that " $[\mathrm{t}]$ he fact that the damage already suffered is slight is no reason for denying the relief given." 190 To respect property rights, and particularly the right to exclude

182. See id. at 201.

183. See id.

184. See id.

185. See Ritz v. Woman's Club of Charleston, 173 S.E. 564, 566 (W. Va. 1934).

186. See id.

187. Williams v. Haile Gold Mining Co., 66 S.E. 117, 118 (S.C. 1909).

188. Evans v. Reading Chem. \& Fertilizing Co., 28 A. 702 (Pa. 1894).

189. See id. (citation omitted).

190. See Shevlin v. Johnston, 205 P. 1087, 1087 (Cal. Dist. Ct. App. 1922) (citation omitted). The court concluded that the party who created the "nuisance should bear the expense of abating it." See id. 
fully, then " $[\mathrm{w}]$ hatever hardship there it must be laid at defendants' door." 191

It is important to note that most of the commentary of nuisance and takings comes from courts worrying about employing a social utility analysis-i.e., courts thinking about sacrificing private property for the gain of public goods. Notably, however, when it comes to considering the harms to the defendant before finding a nuisance, courts would not only be sacrificing private property to public utility but also sacrificing private property for another private party. Takings for private use have, of course, become one of the great problems of recent years. ${ }^{192}$

In the context of nuisance, the Court of Appeals of Maryland observed this problem of nuisance creating a taking for private use, finding that the court " $[\mathrm{knew}]$ of no respectable authority for the principle that one may for his own private gain appropriate his neighbor's property to improve his own because his neighbor's loss will be less than his gain."193 The court finally concluded that none of the authorities for balancing the hardships "can be authority for the proposition that equity . . . will refuse to protect a man in the possession and enjoyment of his property because that right is less valuable to him than the power to destroy it may be to his neighbor or to the public." 194

For this reason, some courts have not been willing to see injunctions as discretionary remedies in the case of a nuisance. The Supreme Court of Georgia observed, "It has been said that the final settlement of property rights does not lie in the broad discretion of the chancellor, but in the clear legal and equitable rules which bind the chancellor himself." 195 The problem with a balancing inquiry when considering whether to issue an injunction is that this allows a court "otherwise having cognizance of the case" to "measure the rights of one party by the cost to the other, committing the injury." 196 The Colorado Supreme Court reasoned:

As it was put in the English cases, it would be a sorry condition of the law if the courts were compelled to hold that the property of another might be taken because it would be either inconvenient or expensive to the one committing the nuisance to restrain or prevent its continuance. ${ }^{197}$

191. See Johnson v. Pattison, 185 N.W.2d 790, 798 (Iowa 1971).

192. See Donald J. Kochan, "Public Use" and the Independent Judiciary: Condemnation in an Interest-Group Perspective, 3 TEx. Rev. L. \& Pol. 49, 51 (1998) (noting need to decrease incidence of takings for private use).

193. See Huebschmann v. Grand Co., 172 A. 227, 230 (Md. 1934).

194. See id.

195. See Holman v. Athens Empire Laundry Co., 100 S.E. 207, 214 (Ga. 1919).

196. See Krebs v. Hermann, 6 P.2d 907, 910 (Colo. 1931).

197. Id. (citation omitted). 
Villanova Law Review, Vol. 62, Iss. 4 [2017], Art. 2

The balancing doctrine "has been subject to criticism as an odious method by which the larger property owner always has the advantage over the smaller." 198

State supreme courts around the country engaged this question of the relationship between nuisance and takings, concluding that to deprive the plaintiff of her compensatory damages would be to make a taking of property. Where the court rejects the claim of nuisance due to the social utility of the defendant's conduct, what the court is doing is allowing the plaintiff's property to be reduced in value for the benefit of the public and without compensation. Worse, where the court balances the harms to the private defendant and then refuses to allow a claim for nuisance, the court is effectively creating a taking not for public purposes, but indeed for private ones. The plaintiff's property reduces in value to benefit the property of the defendant. The first scenario is bad, the second even worse. Both should offend our understanding of how private property is constitutionally protected within this country.

\section{B. Diminishing Rights to Possession and the Future of Nuisance Law}

Property focuses much of its attention and energy on the idea of possession, which may be the fundamental determining feature of a property claim. ${ }^{199}$ Theorists who greatly disagree about the nature of property and its best and most useful ends still tend to congregate around the idea of possession as the touchstone. ${ }^{200}$ Common law history tends to grant possession a primary place in determining property ownership rights. ${ }^{201}$ The right of exclusive possession is "the bedrock of English land law." 202 Richard A. Epstein has described possession as "the backbone of the common law system of property rights." 203 William Blackstone translates possession into occupancy, but retains a similar idea, noting that "occupancy is the

198. See Heppenstall Co. v. Berkshire Chem. Co., 11 Conn. Supp. 82, 91-92 (Super. Ct. 1942) (citation omitted).

199. See generally Richard A. Epstein, Possession as the Root of Title, 13 GA. L. REv. 1221 (1979).

200. See, e.g., Richard A. Posner, Economic Analysis of Law reprinted in Perspectives on Property Law 54, 55-56 (Robert C. Ellickson et al. eds., 2002) (applying economic analysis and focusing on possession); Margaret Jane Radin, Reinterpreting Property 35-71 (1993) (focusing on possession within personhood analysis); Carol M. Rose, Property \& Persuasion: Essays on the HisTORY, TheORY, AND RHeTORIC OF OWNERShip 11-23 (1994) (focusing on possession in more communication-focused idea of property).

201. See Epstein, supra note 199, at 1222.

202. See Hunter v. Canary Wharf Ltd [1997] AC 655 (HL) 703 (appeal taken from Eng.). With that said, Carol Rose has argued that William Blackstone would have seen the right of exclusive possession as an "ideal type rather than a reality." See Carol M. Rose, Canons of Property Talk, or, Blackstone's Anxiety, 108 Yale L.J. 601, 604 (1998) (citation omitted).

203. See Richard A. Epstein, How to Create-or Destroy-Wealth in Real Property, 58 Ala. L. Rev. 741, 742 (2007). 
thing by which the title was in fact originally gained." 204 We have remained attached to these ideas, despite the fact that possession is often poorly defined and, worse, used circularly to define property. Despite any flaws, possession is at the center of our ideas of property and at the heart of the rights we believe we are protecting as property interests.

Possession is also at the heart of the idea of a nuisance claim. Generally, a definition of a nuisance claim begins by speaking of a "non-trespassory" invasion. ${ }^{205}$ This is because "[i]nterests in the exclusive possession of land are distinguished from interests in the use and enjoyment of it."206 The difference between the two determines whether the plaintiff should pursue a trespass action for an entry to the property instead of a nuisance action for an interference with the enjoyment of the property. ${ }^{207}$ So, the heart of the nuisance claim is the protection of the plaintiff's right of non-exclusive possession, but more generally, undisturbed possession. Thus, when the doctrine of nuisance balances social utility and harms to the defendant within the prima facie case, the courts make it more difficult for plaintiffs to succeed in nuisance actions, thereby offering much more limited protection to the right of undisturbed possession-a central notion of what it means to have property rights.

Such curtailing of property rights is not an insignificant move by the courts. It is all the more alarming that such changes appear to have happened in the last half century without much in the way of public debate or significant analysis by scholars. We have allowed rights to creep away, slowly, and without notice. ${ }^{208}$ For whatever reason, modern courts have not paid significant attention to the takings problem that so troubled courts in the earlier half of the twentieth century.

One explanation for this lack of awareness may be the collapse of the distinction between law and equity. At one time the courts of law would have had one definition for nuisance that would be used in cases seeking money damages, while courts of equity would have had their own definition of nuisance to be used in cases where the plaintiff sought an injunction. The different jurisdictional scopes of the two courts would have kept these two different doctrines relatively separate-an issue that the Restate-

204. See William Blackstone, Commentaries on the Laws of England, $r$ printed in Perspectives on Property Law 45, 51 (Robert C. Ellickson et al. eds., 2002).

205. See Restatement (First) of Torts, supra note 124, § 822, at 226.

206. See id. at 224-25.

207. See id. at 225.

208. This is perhaps all the more remarkable given that in general, citizens are always seeking additional and more effective methods of protecting their assets, including optimizing all possible routes to successful litigation. In the context of securities regulation, for example, plaintiffs continually push to utilize state laws that may provide for better verdicts, while avoiding the constraints of federal claims. See generally Benjamin P. Edwards, Disaggregated Classes, 9 VA. L. \& Bus. Rev. 305, 306-307 (2015). 
ment (First) of Torts notes as problematic. ${ }^{209}$ By simply merging the two doctrines as the two jurisdictions merged, courts may have simply not given particular attention to how the differences had performed an important function in protecting the rights of plaintiffs to money damages, even if the courts would not be willing to grant an injunction due to the strong social benefits of the defendant's actions.

Whether the modern doctrine emerged from inattention or the confusion of merging courts of law and equity, the current rule poorly serves to protect private property. Indeed, the current rule places an unreasonable burden on plaintiffs who wish to bring a case for nuisance, even if the plaintiffs are seeking only compensatory damages. If the offending use is beneficial to the public, plaintiffs are extremely unlikely to succeed on a claim for nuisance-even where they can demonstrate substantial harmsnot only in terms of everyday annoyances, but also in terms of clear drops in their property values. Additionally, such plaintiffs are likely to be without another remedy; no other cause of action works in the same way to protect against such external interferences that reduce property values.

In light of the danger of takings, particularly for public purposes such as industrial development, I argue that the doctrine of nuisance should again transform. Specifically, courts should reconstruct the earlier doctrines of nuisance that specifically took into account whether the plaintiff was seeking damages in equity or at law. I propose that courts return to their previous jurisprudence, which curtailed balancing (in terms of harms to the defendant or harms to the public interest) to the approval or denial of injunctive remedies. Balancing should not be a part of the prima facie case for a nuisance. If it is, there is always the limiting of the plaintiff's property rights in favor of someone else-either the defendant or the public. If balancing of either public or private interests is a part of the prima facie case for nuisance, and the plaintiff is unable to recover money damages because the plaintiff cannot prove the prima facie case, then there will be an uncompensated taking of her property for either public or private purposes. For this reason, the rule that would better protect private property and avoid uncompensated takings would be a rule that includes balancing only within questions of equitable remedies, allowing compensatory damages to be available as a matter of right when the plaintiff proves the remaining elements of a case of nuisance.

\section{Conclusion}

Despite the importance of nuisance law both as a tool of theoretical inquiry and as a baseline of doctrine for a variety of legal fields, little has been written about the evolution of nuisance law. ${ }^{210}$ Indeed, scholars have entirely ignored the changes that have taken place in nuisance law within the last half of the twentieth century. By focusing on the idea that

209. See Restatement (First) of Torts, supra note 124, at 223-24.

210. See supra notes 11-15 and accompanying text. 
balancing was introduced at the end of the 1800s, scholars did not question whether balancing had ever become a significant part of the nuisance analysis, as opposed to a heavily limited portion of the inquiry. Additionally, scholars failed to question what the introduction of balancing did to plaintiffs' property rights.

This Article focused on detailing the many ways that courts originally limited balancing, keeping it from playing any significant role in limiting the scope of nuisance rights of plaintiffs. ${ }^{211}$ The Article then detailed how the many limitations on the balancing inquiry were dropped during the mid-to-late twentieth century. ${ }^{212}$ During this process I argued balancing became a part of the prima facie case for nuisance, significantly reducing the rights that property owners have in nuisance to protect their properties from interference. ${ }^{213}$ I described how courts had originally limited balancing severely, based on the idea that to fail to do so would be to invite takings claims. ${ }^{214}$ While modern courts have ignored the takings problem, I discussed the many concerns of courts in earlier decades and concluded that modern courts should reconsider whether balancing should ever take place within the prima facie case for nuisance given that doing so deprives plaintiffs not only of their equitable remedies, but also their damages at law. ${ }^{215}$

211. See supra notes $25-58$ and accompanying text.

212. See supra notes 59-142 and accompanying text.

213. See supra notes 143-79 and accompanying text.

214. See supra notes $180-98$ and accompanying text.

215. See supra notes 199-210 and accompanying text. 